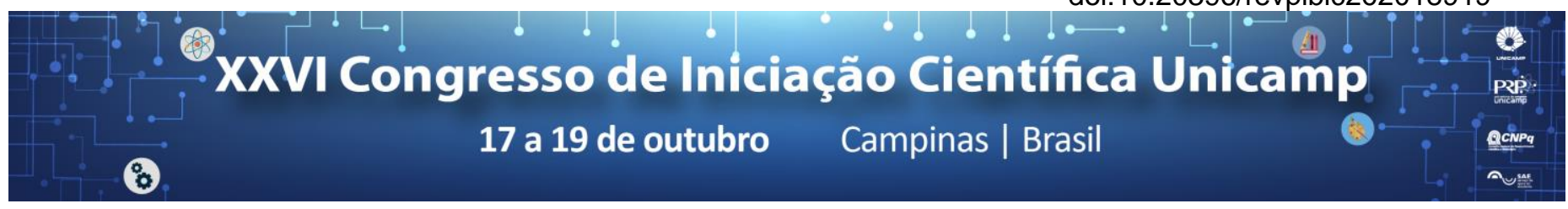

\title{
Determinação do espaçamento dendrítico no aço AISI M2.
}

\section{Luis Felipe Mira*, Gabriel Hideki Shinkawa, Paula Fernanda da Silva Farina.}

\section{Resumo}

O aço rápido AISI M2, quando produzido via lingotamento convencional, pode apresentar diferentes estruturas ao longo do lingote, as quais refletem em diferentes propriedades mecânicas. As principais variações para esta classe de aço são quanto ao tipo, fração volumétrica e morfologia dos carbonetos e ao espaçamento dendrítico da ferrita. Neste trabalho serão determinados os espaçamentos dendríticos primários e secundários para duas diferentes temperaturas de fusão e três posições do lingote. As amostras foram preparadas convencionalmente para metalografia e atacadas com o reagente Nital e as imagens para as medições foram obtidas por microscopia ótica. Foi verificado que, apesar do grande erro experimental, há uma tendência a aumentar o espaçamento dendrítico com a diminuição da taxa de resfriamento.

\section{Palavras-chave:}

Metalografia, espaçamento dendrítico, taxa de resfriamento.

\section{Introdução}

Aço ferramenta é uma categoria de ligas metálicas utilizadas para a manufatura de ferramentas e moldes. ${ }^{1}$

Aços rápido são uma classe de aços ferramenta capazes de manter resistência ao desgaste abrasivo e alta dureza, em operações em temperaturas elevadas. ${ }^{1}$

Tais propriedades são fortemente relacionadas aos carbonetos dispersos na microestutura, composição da liga, rota de procesamento e tratamentos térmicos aplicados. ${ }^{1}$

O espaçamento dendrítico é um importante parâmetro que reflete como a taxa de resfriamento, um dos mecanismos da cinética de solidificação, afeta a microestrutura, impactando nas propriedades do material.

Este trabalho visa determinar o espaçamento dendrítico primário e secundário em função da taxa de resfriamento para o aço rápido AISI M2.

\section{Resultados e Discussão}

Foi realizada a preparação metalográfica das amostras do aço AISI M2, seguindo o procedimento padrão, composto das etapas de corte, lixamento, polimento, ataque químico com Nital, e observação em microscópio ótico.

A partir das imagens obtidas (Figura 1.), foi realizada a medição dos espaçamentos dendríticos primários e secundários, e seus respectivos devios, em três distintas regiões dos lingotes, obtidos em duas corridas realizadas as temperaturas de $1515^{\circ} \mathrm{C}$ e $1675^{\circ} \mathrm{C}$.

Verificou-se uma tendência de aumento no espaçamento dendrítico entre as posições 1 e 3 , que correspondem as regiões de maior e menor taxa de resfriamento, respectivamente, conforme representado pelas figuras 2 e 3 .

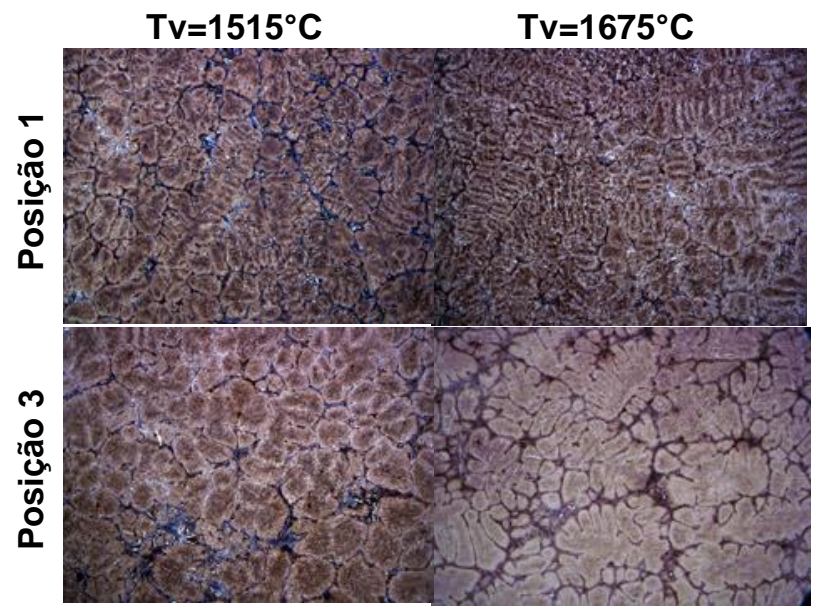

Figura 1. Microestruturas do AISI M2 em diferentes posições dos lingotes, com temperaturas de vazamento de $1515^{\circ} \mathrm{C}$ e $1675^{\circ} \mathrm{C}$. $100 x$. Ataque em Nital $2 \%$.

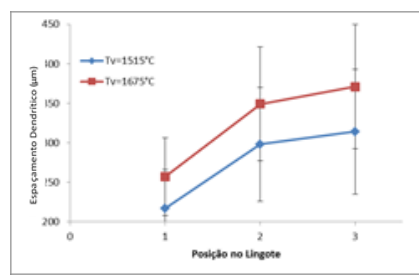

Figura 2. Espaçamento dendrítico primário

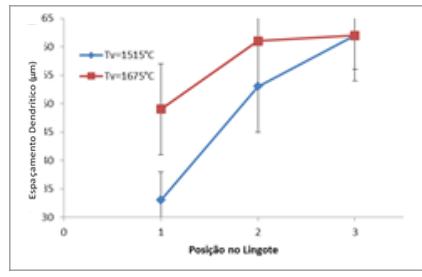

Figura 3. Espaçamento dendrítico secundário

\section{Conclusões}

Foi verificado que uma redução na taxa de resfriamento dos lingotes provoca refino das dendritas para o AISI M2, sendo, portanto, um parâmetro que reflete nas propriedades dessa liga de aço rápido.

\section{Agradecimentos}

Ao CNPq pela bolsa de iniciação científica.

1ROBERTS, G; KRAUSS, G; KENNEDY, R. Tool Steels. ASM International, 1998. 